\title{
Is peniaphobia an incentive to crime?
}

\begin{abstract}
Siti Nur Zahara Hamzah and Evan Lau*
Department of Economics, Universiti Malaysia Sarawak, Kota Samarahan, Malaysia

This article analysed the relationship between crime categories and unemployment rates using a set of panel data for 14 states in Malaysia with data spanning from 1982 to 2008. It is well documented that crime and unemployment are negatively related in Malaysia; the same is the case for both violent and property crime. Increases in unemployment rates cause the consumption expenditure to decrease, especially among households, hence, causing potential earnings from illegitimate activities to drop and discouraging a person from committing a crime. However, the significant properties of the $t$-statistics indicate that it is important to consider the labour market conditions in employing appropriate policies in fighting crime. That being said, unemployment can indirectly explain hunger, poverty, decreasing standards of life and economic downturn.
\end{abstract}

Keywords: unemployment; crime; panel data analysis; Malaysia

\section{Introduction}

The crime-unemployment nexus is one of the most antediluvian issues in the social science literature. However, consensus on the causal linkages between unemployment and crime has yet to be achieved. ${ }^{1}$ Explaining crime in an economic model allows for the assumption of rational choice theory that outweighs costs (preparation, conviction and apprehension) and benefits (profits) before engaging in illegitimate activities. ${ }^{2}$ Basically, the economics

*Corresponding author. Email: lphevan@feb.unimas.my; ygwiex@yahoo.com

1. R. Freeman, 'Crime and the Labour Market', in Crime and Public Policy, ed. J.Q. Wilson (San Francisco, CA: Institute for Contemporary Studies, 1983), 89-106; S.K. Long and A.D. Witte, 'Current Economic Trends: Implications for Crime and Criminal Justice', in Crime and Criminal Justice in a Declining Economy, ed. K.N. Wright (Cambridge, MA: Oelgeschlager, Gunn, and Hain, 1981), 69-143; and R. Freeman and W.M. Rodgers, 'Area Economic Conditions and the Labor Market Outcomes of Young Men in the 1990s Expansion' (working paper no. 7073, National Bureau of Economic Research, 1999).

2. B. Fleisher, 'The Effects of Unemployment on Juvenile Delinquency', Journal of Political Economy 71 (1963): 543-55; B. Fleisher, 'The Effects of Income on Delinquency', American Economic Review 56 (1966): 118-37; G.S. Becker, 'Crime and Punishment: An Economic Approach', Journal of Political Economy 76 (1968): 1169-217; I. Ehrlich, 'Participation in Illegitimate Activities: A Theoretical and Empirical Investigation', Journal of Political Economy 38 (1973): 521-65; I. Ehrlich, 'On the Usefulness of Controlling Individuals: An Economic Analysis of Rehabilitation, Incapacitation, and Deterrence', American Economic Review 71 (1981): 307-22; I. Ehrich, 'Crime, Punishment, and the Market for Offenses', Journal of Economic Perspectives 10 (1996): 43-68; I. Ehrich, 'Crime, Punishment, and the Market for Offenses', Journal of Economic Perspectives 10 (1996): 43-68; and S.D. Levitt, 'Using Electoral Cycles in Police Hiring to Estimate the Effect of Police on Crime', American Economic Review 87 (1997): 270-90. 